\title{
EFFECT OF MIYODO ON GROWTH, YIELD ATTRIBUTES AND YIELD IN T. AMAN RICE cv. BR-11
}

\author{
A. K. M. Golam Sarwar, J. Sultana, M. O. Islam and A. K. M. A. Prodhan \\ Department of Crop Botany, Bangladesh Agricultural University \\ Mymensingh-2202, Bangladesh
}

\begin{abstract}
An experiment was conducted in the field laboratory of the Department of Crop Botany, Bangladesh Agricultural University, Mymensingh, to investigate the effect of foliar application of Miyodo on morphology, yield contributing characters and yield of T. aman rice cv. BR-11. The concentrations of Miyodo used were $2 \mathrm{mgL}^{-1}, 3 \mathrm{mgL}^{-1}, 4 \mathrm{mgL}^{-1}$ and $5 \mathrm{mgL}^{-1}$ with a control. The experiment was laid out in a randomized complete block design with three replications. Application of Miyodo by spraying at 45 days after transplanting significantly enhanced plant height, number of tillers and effective tillers, number of leaves and leaf area, size of flag leaf, total dry matter, panicle length, number of total grains and filled grains, 1000-grain weight, grain yield, straw yield, and harvest index. The result showed that the application of $5 \mathrm{mgL}^{-1}$ Miyodo produced the highest grain yield of BR-11 compared to other concentrations as well as control. However, further study is needed to determine the higher concentration limit of Miyodo in maximizing the growth and yield of T. aman rice cv. BR-11.
\end{abstract}

Key words : Miyodo, T. aman rice cv. BR-11, Growth, Yield attributes, Yield

\section{INTRODUCTION}

During the recent food grain deficit, the importance of rice (Oryza sativa L.) crop has become a major issue of discussion in perspective of food security and socio-economic development in Bangladesh. Although about $76.27 \%$ of the total cultivated land covering 10 million hectares is under rice cultivation, the food deficit is increasing day by day at an alarming rate due to higher population increment rate (ca. 1.43\%) in our country (BBS, 2006). One of the causes of rice grain shortage is low yield of rice. The average yield ( 3.87 tha $^{-1}$ ) of rice in Bangladesh is low compared to other rice growing countries of the world viz., Japan 6.51tha- ${ }^{-1}$ and China 6.24tha ${ }^{-1}$ (IRRI, 2008). Furthermore, the cultivable land is decreasing in alarming rate due to contribution of buildings, houses, industries, new roads and highways. Expansion of land under rice cultivation is almost impossible, therefore, increment in rice yield hectare ${ }^{-1}$ is might one of the ways to overcome the grain food deficit in Bangladesh. Modern varieties, HYVs and hybrids, and improved management practices might be the possible tools for increasing hectare-1 yield of rice.

Application of plant growth regulators (PGRs) is one of the management practices, being used as an aid to enhance yield (Nickell, 1982). Recently, there has been global realization of the important role of PGRs in crop production especially in better growth and enhancing yield of different crops (Prasad and Paudel, 1994). PGRs improve crop yield by 
enhancing the different processes of plant growth and development. Most of the PGRs exhibit a broad action spectrum and thus a single hormone may influence entirely different processes of the plant. So, favourable process may be induced by applying PGRs exogenously in proper concentration at a proper time in a specified crop. The commercial productions of PGRs are used mainly in horticultural crops and next for rice (Park, 1995). Miyodo, a relatively new synthetic plant growth regulator in Bangladesh, was collected from Dr. Yasuo Kamuro, Marketing Director, BAL Planning Company Ltd., Ichinomiya, Japan. Miyodo was formulated mainly for improving growth and yield of leafy vegetables and horticultural crops. Moreover, it has reported that Miyodo enhanced growth, yield contributing characters and yield of some field crops (Rahman, 2006; Reza, 2006; Sarker, 2006), but literature regarding the effect of Miyodo on cereal crops is very scanty (Islam, 2007; Islam et al., 2008). Therefore, the present research was conducted to assess the effect of Miyodo on morphology, yield contributing characters and yield of T. aman rice cv. BR-11 and to find out the effective concentration of Miyodo for getting higher yield in BR-11.

\section{MATERIALS AND METHODS}

The experiment was carried out at the Field Laboratory of the Department of Crop Botany, Bangladesh Agricultural University, Mymensingh, from July to December, 2007. One of the most popular transplant aman rice cultivars BR-11 was used as plant material. The concentrations of Miyodo used were $2 \mathrm{mgL}^{-1}, 3 \mathrm{mgL}^{-1}, 4 \mathrm{mgL}^{-1}$ and $5 \mathrm{mgL}^{-1}$ with a control. The experiment was laid out in a Randomized Complete Block Design (RCBD) with three replications. Healthy rice seedlings of 33 days old were transplanted at the spacing of $15 \mathrm{~cm} \times 20 \mathrm{~cm}$ (plant-plant $\times$ row-row) on $26^{\text {th }}$ July, 2007. The standard rice cultivation procedure was followed as indicated by BRRI (2005).

Foliar application of Miyodo was done at 45 days after transplanting (DAT). The data on number of leaves and leaf area hill-1 ${ }^{-1}$ were collected at 85 DAT, and other morphological features viz., plant height, number of tillers hill-1 ${ }^{-1}$ number of leaves hill-1 ${ }^{-1}$ total leaf area hill $^{-1}$, flag leaf area and total dry matter, were collected at 105 DAT. At final harvest (117 DAT), plant samples were collected from each plot $(2 \mathrm{~m} \times 3 \mathrm{~m})$ and data on number of effective tillers hill-1, panicle length, number of spikelets panicle- ${ }^{-1}$, number of filled and unfilled grains panicle ${ }^{-1}, 1000$-grain weight, grain yield and straw yield were collected, and the harvest index was calculated. Collected data were statistically analyzed by using the computer software program MSTAT-C and the difference between means was adjudged by Duncan's New Multiple Range Test (DMRT).

\section{RESULTS AND DISCUSSION}

\section{Effect of Miyodo on morphological and growth characters of BR-11}

The Miyodo had stimulatory effect on plant height (Table 1). Result revealed that plant height increased with the increase of concentrations, but there was no significant difference among the concentrations of Miyodo except at $2 \mathrm{mgL}^{-1}$ of Miyodo (Table 1). The tallest plant $(118.52 \mathrm{~cm})$ was found with $5 \mathrm{mgL}^{-1}$ Miyodo and the shortest was in control $(108.64 \mathrm{~cm})$. Islam (2007) reported that Miyodo application increased plant height 
in boro rice (BRRI dhan-29). This result agrees with the earlier results. Plant height increment might be the result of cell expansion, cell elongation and cell division which increased the number and/or length of internodes. The application of Miyodo might have stimulatory effect which influenced the biological activities that ultimately led to stem elongation in rice plant.

Table 1. Effect of different concentrations of Miyodo on morphological and growth characters of BR-11

\begin{tabular}{|c|c|c|c|c|c|c|c|c|}
\hline \multirow{2}{*}{$\begin{array}{c}\text { Miyodo } \\
\text { concentration }\end{array}$} & \multirow{2}{*}{$\begin{array}{l}\text { Plant } \\
\text { height } \\
(\mathrm{cm})\end{array}$} & \multirow{2}{*}{$\begin{array}{c}\text { Number } \\
\text { of tillers } \\
\text { hill-1 }^{-1}\end{array}$} & \multirow{2}{*}{$\begin{array}{l}\text { Number of } \\
\text { effective } \\
\text { tillers hill-1 }\end{array}$} & \multirow{2}{*}{$\begin{array}{c}\text { Number } \\
\text { of leaves } \\
\text { hill-1 }^{-1}\end{array}$} & \multirow{2}{*}{$\begin{array}{l}\text { Leaf area } \\
\text { hill- }^{-1}\left(\mathrm{~cm}^{2}\right)\end{array}$} & \multicolumn{2}{|c|}{ Flag leaf } & \multirow{2}{*}{$\begin{array}{c}\text { Total dry } \\
\text { matter }(\mathrm{g})\end{array}$} \\
\hline & & & & & & $\begin{array}{l}\text { Length } \\
(\mathrm{cm})\end{array}$ & $\begin{array}{l}\text { Area } \\
\left(\mathrm{cm}^{2}\right)\end{array}$ & \\
\hline Control & $108.64 b$ & $13.53 b$ & $11.41 \mathrm{e}$ & $41.93 \mathrm{~d}$ & $954.60 d$ & $23.78 \mathrm{~d}$ & $163.11 \mathrm{c}$ & $58.27 \mathrm{c}$ \\
\hline $2 \mathrm{mgL}^{-1}$ & $111.47 \mathrm{~b}$ & $14.08 \mathrm{~b}$ & $12.26 \mathrm{~d}$ & $50.41 \mathrm{c}$ & $1186.50 \mathrm{c}$ & $25.43 \mathrm{c}$ & $169.08 \mathrm{bc}$ & $62.67 \mathrm{bc}$ \\
\hline $3 \mathrm{mgL}^{-1}$ & 113.64ab & $15.55 \mathrm{ab}$ & $13.22 \mathrm{c}$ & $53.19 \mathrm{bc}$ & $1480.00 \mathrm{~b}$ & $26.87 \mathrm{~b}$ & $179.55 b$ & $67.90 \mathrm{~b}$ \\
\hline $4 \mathrm{mgL}^{-1}$ & $115.80 \mathrm{ab}$ & $16.50 \mathrm{a}$ & $14.03 b$ & $55.25 \mathrm{~b}$ & $1586.50 \mathrm{~b}$ & $27.83 \mathrm{~b}$ & 187.79ab & $77.37 \mathrm{a}$ \\
\hline $5 \mathrm{mgL}^{-1}$ & $118.52 \mathrm{a}$ & $16.64 a$ & $14.62 \mathrm{a}$ & $63.66 a$ & $1755.50 \mathrm{a}$ & $28.31 \mathrm{a}$ & 194. $54 a$ & $74.24 a$ \\
\hline LSD (0.05) & 4.88 & 1.76 & 0.36 & 4.69 & 161.7 & 1.03 & 12.74 & 5.86 \\
\hline
\end{tabular}

In a column, figures with common letter(s) do not differ significantly at $5 \%$ level as per DMRT

The number of tillers is one of the most important factors for yield. Tiller production especially the number of effective tillers is the potential factor for yield component. Both the number of tillers and effective tillers hill ${ }^{-1}$ was significantly increased with the concentrations of Miyodo (Table 1). At the concentration of $5 \mathrm{mgL}^{-1}$, Miyodo produced both the largest number of tillers and effective tillers hill-1 $(16.64$ and 14.62 , respectively) and the lowest was in control (13.53 and 11.41, respectively). Similar trend was reported by Islam (2007). He observed that higher concentration of Miyodo (4 mgL-1) produced both the highest number of tillers and effective tillers hill-1 ${ }^{-1}$ ompared to control.

Leaf area, a measure of leafiness and photosynthetic area of crop, depends on the leaf growth and number of leaves. Leaf area is one of the most important growth characters of plant on which crop yield depends. The number of leaves was highest at maximum tillering stage of growth and decreased thereafter (Sultana, unpublished data). The decreased in leaf number at later stages of growth might be due to senescence or drying up of leaves. Application of Miyodo at different concentrations stimulated leaf number as well as leaf area hill-1 (Table 1). The highest leaf number and leaf area (63.66 and 1755.50 $\mathrm{cm}^{2}$, respectively) were obtained at $5 \mathrm{mgL}^{-1}$ of Miyodo, both decreased gradually with the decreasing concentrations of Miyodo. But this observation was not true for flag leaves. Although the length of flag leaves was statistically significant at the concentrations 4 $\mathrm{mgL}^{-1}$ and $5 \mathrm{mgL}^{-1}$ of Miyodo, the area of flag leaves was statistically insignificant (Table 1). The higher leaf number indicates the larger photosynthetic area which may be one of the causes for higher yield in Miyodo treated rice plant. The result obtained from the present study is consistent with the results of previous researchers (Islam, 2007; Islam et al., 2008). 
Total dry matter (TDM) is the sum of dry weight of shoot and root. The effect of Miyodo in inducing dry matter accumulation in plants was the lower in the early stages of growth, but it became pronounced at later stages. The highest concentration $\left(5 \mathrm{mgL}^{-1}\right)$ of Miyodo produced the highest TDM (74.24g) which was statistically similar with $4 \mathrm{mgL}^{-1}$ and control had the lowest $(58.27 \mathrm{~g}$ ) (Table 1). The result was supported by the results of previous researchers (Islam, 2007; Islam et al., 2008). Higher TDM production in Miyodo treated plants might be the combined effect of larger plant height with higher number of tillers and leaves.

\section{Effect of Miyodo on yield contributing characters and yield in BR-11}

The effect of Miyodo concentrations was significant on all the yield contributing characters studied except harvest index (Table 2). The highest values of panicle length, number of spikelets and filled grains panicle-1, 1000-grain weight, grain and straw yield $\left(27.17 \mathrm{~cm}, 208.98,195.53,25.03 \mathrm{~g}, 6.15\right.$ tha $^{-1}$ and 6.27 tha $^{-1}$, respectively), and the lowest number of unfilled grains panicle ${ }^{-1}$ (11.97) were observed at the Miyodo concentration at $5 \mathrm{mgL}^{-1}$. The lowest values of panicle length, number of spikelets and filled grains panicle1, 1000-grain weight, grain and straw yield $\left(23.82 \mathrm{~cm}, 166.33,123.89,23.48 \mathrm{~g}, 4.63\right.$ tha $^{-1}$ and 5.42 tha $^{-1}$, respectively), and the highest number of unfilled grains panicle ${ }^{-1}$ (42.44) were found at the control (Table 2). The highest grain yield at Miyodo concentration of $5 \mathrm{mgL}^{-1}$ might be due to the enhancing effect of Miyodo on the yield contributing characters especially number of spikelets and filled grains panicle ${ }^{-1}$. The present result agrees with the findings of previous studies (Islam et al., 2008).

Table 2. Effect of different concentrations of Miyodo on the yield contributing characters and yield of BR-11

\begin{tabular}{l|c|c|c|c|c|c|c|c}
\hline $\begin{array}{c}\text { Miyodo } \\
\text { concentra- } \\
\text { tion }\end{array}$ & $\begin{array}{c}\text { Panicle } \\
\text { length } \\
(\mathrm{cm})\end{array}$ & $\begin{array}{c}\text { Number } \\
\text { of spikelets } \\
\text { panicle }\end{array}$ & $\begin{array}{c}\text { Number of } \\
\text { filled grains } \\
\text { panicle- }\end{array}$ & $\begin{array}{c}\text { Number of } \\
\text { unfilled grains } \\
\text { panicle }\end{array}$ & $\begin{array}{c}\text { 1000-grain } \\
\text { weight }(\mathrm{g})\end{array}$ & $\begin{array}{c}\text { Grain } \\
\text { yield } \\
\left(\mathrm{t} \mathrm{ha}^{-1}\right)\end{array}$ & $\begin{array}{c}\text { traw } \\
\text { yield } \\
(\mathrm{t} \mathrm{ha}-1)\end{array}$ & $\begin{array}{c}\text { Harvest } \\
\text { index } \\
(\%)\end{array}$ \\
\hline Control & $23.82 \mathrm{~b}$ & $166.33 \mathrm{c}$ & $123.89 \mathrm{c}$ & $42.44 \mathrm{a}$ & $23.48 \mathrm{c}$ & $4.63 \mathrm{c}$ & $5.41 \mathrm{c}$ & $46.17 \mathrm{~b}$ \\
$2 \mathrm{mgL}^{-1}$ & $24.61 \mathrm{~b}$ & $173.35 \mathrm{bc}$ & $141.51 \mathrm{c}$ & $35.75 \mathrm{~b}$ & $24.36 \mathrm{~b}$ & $5.30 \mathrm{~b}$ & $5.67 \mathrm{bc}$ & $48.31 \mathrm{a}$ \\
$3 \mathrm{mgL}^{-1}$ & $26.22 \mathrm{a}$ & $181.47 \mathrm{bc}$ & $152.47 \mathrm{bc}$ & $32.73 \mathrm{~b}$ & $24.84 \mathrm{a}$ & $5.55 \mathrm{~b}$ & $5.79 \mathrm{~b}$ & $48.98 \mathrm{a}$ \\
$4 \mathrm{mgL}^{-1}$ & $26.77 \mathrm{a}$ & $187.44 \mathrm{~b}$ & $165.54 \mathrm{~b}$ & $21.88 \mathrm{c}$ & $24.95 \mathrm{a}$ & $5.98 \mathrm{a}$ & $6.17 \mathrm{a}$ & $49.25 \mathrm{a}$ \\
$5 \mathrm{mgL}^{-1}$ & $27.17 \mathrm{a}$ & $208.98 \mathrm{a}$ & $193.53 \mathrm{a}$ & $11.97 \mathrm{~d}$ & $25.03 \mathrm{a}$ & $6.15 \mathrm{a}$ & $6.27 \mathrm{a}$ & $49.53 \mathrm{a}$ \\
\hline LSD $(0.05)$ & 1.12 & 4.59 & 20.29 & 18.00 & 0.46 & 0.26 & 0.28 & 1.27 \\
\hline
\end{tabular}

In a column, figures with common letter (s) do not differ significantly at $5 \%$ level as per DMRT

Harvest index (HI) is a very important character of yield component parameter which reflects the efficiency of translocation or alternatively dry matter partitioning of a given genotype to it's economic part. Data on $\mathrm{HI}$ of present experiment were presented in Table 2 and showed that Miyodo application resulted a significant effect on HI, but among the concentrations the effect was non-significant. However, numerically the highest HI (49.53) was obtained at $5 \mathrm{mgL}^{-1}$ and the lowest (46.17) was found at the control. This result confirmed the results of previous studies (Islam, 2007; Islam et al., 2008). 
Although the HI did not differ significantly among different concentrations of Miyodo, the highest grain yield in BR-11 at $5 \mathrm{mgL}^{-1}$ of Miyodo might be due to the higher TMD produced at the same concentration (Table 1).

From the result, it may be concluded that Miyodo treated rice plant showed better performance in growth, yield and yield attributes. Miyodo at the $5 \mathrm{mgL}^{-1}$ might be the suitable concentration for higher yield in BR-11. However, further research is needed with some higher concentrations of Miyodo to find out the suitable concentration to maximize the growth and yield in BR-11.

\section{REFERENCES}

BBS. 2006. Statistical Year Book of Bangladesh. Bangladesh Bureau of Statistics (BBS), Stat. Div., Min. Planning, Govt. Peoples Repub. Bangladesh, Dhaka.

BRRI. 2005. Some appropriate technologies of rice cultivation. Thana Cereal. Bangladesh Rice Res. Inst. (BRRI), Joydebpur, Gazipur.

IRRI. 2008. Rough rice yield, by country and geographical region-USDA 1961-2007. International Rice Res. Inst. (IRRI), Los Banos, Philippines. http://www.irri.org/ science/ricestat/data/may 2008/WRS2008-Table03-USDA.pdf

Islam, M. Z. 2007. Effect of Miyodo on growth and yield of boro rice (BRRI dhan-29). M. S. Thesis, Department Crop Botany, Bangladesh Agricultural University, Mymensingh.

Islam, M. M., Mondal, M. A. Ali, M. M., Akther, Q. Y. Begum, M. Z. F. A. and Prodhan, A. K. M. A. 2008. Effect of foliar application of GABA and Miyodo growth regulators on yield and yield attributes in wheat. J. Agrofor. Environ. 2(1): 131-135.

Nickell, L. G. 1982. Plant growth regulators- Agricultural uses. Springer-Verlag, Berlin.

Park, M. E. 1995. Recent research achievement and problems of plant growth regulator in the Republic of Korea. Paper presented at the symposium on regional co-operation in plant growth regulators for Asia and Pacific. 4-12 Oct. 1995, Beijing, China.

Prasad, B. N. and Paodel, R. 1994. Effect of ABT-7 on seedling growth and some biochemical parameters in buck wheat. In: Technology for Plant Growth Regulators, Beijing. p. 2-12.

Rahman, M. M. 2006. Effect of Miyodo and PDJ on growth and yield attributes of mungbean. M. S. Thesis, Department Crop Botany, Bangladesh Agricultural University, Mymensingh.

Reza, M. S. 2006. Changes in growth and yield of garlic as influenced by Miyodo hormone and clove size. M. S. Thesis, Department Crop Botany, Bangladesh Agricultural University, Mymensingh.

Sarker, M. K. 2006. Effect of Miyodo on growth and yield in soybean. M. S. Thesis, Department Crop Botany, Bangladesh Agricultural University, Mymensingh. 